\title{
0 abade, o poeta e o charlatão: reflexões acerca de esoterismo e política nos séculos XV e XVI
}

The abbot, the poet and the charlatan: reflections on esotericism and politics in the Fifteenth and Sixteenth centuries

Francisco de Paula Sousa Mendonça Júnior ${ }^{*}$

Universidade Federal de Santa Maria (UFSM), Santa Maria, RS, Brasil

\begin{abstract}
RESUMO: O presente artigo discutirá a maneira pela qual esoterismo e política se relacionaram ao longo dos séculos XV e XVI. Para tanto, tomaremos como personagens o bispo alemão Johannes Trithemius (1462-1512), o poeta e dramaturgo italiano Giambattista della Porta (c. 1540-1615) e o jurista e médico alemão Heinrich Cornelius Agrippa von Nettesheim (1486-1535), bem como suas principais obras, respectivamente, a Steganographie: Ars per occultam Scripturam animi sui voluntatem absentibus aperiendi certu (c. 1500), a Magiae naturalis, sive de miraculis rerum naturalium libri IIII (1558) e a De Occulta Philosophia libri tres (1533). Amparados pelas ferramentas teóricas da história do segredo e da história do esoterismo, discutiremos as contribuiçôes do esoterismo para a complexa transição do regimen animarum para a Razão de Estado.
\end{abstract}

PALAVRAS-CHAVE: Esoterismo. Política. Renascimento.

\begin{abstract}
The present article will discuss the way in which esotericism and politics were related throughout the XV and XVI centuries. Therefore, we will take as characters the German bishop Johannes Trithemius (1462-1512), the Italian poet and playwright Giambattista della Porta (c. 1540-1615) and the German jurist and physician Heinrich Cornelius Agrippa von Nettesheim (1486-1535), as well as his major works, respectively, the Steganographie: Ars per occultam Scripturam animi sui voluntatem absentibus aperiendi certu (c. 1500), Magiae naturalis, sive of miraculis rerum naturalium libri IIII (1558) and De Occulta Philosophia libri tres (1533). Supported by the theoretical tools of history of secret and the history of esotericism, we will discuss the contributions of esotericism to the complex transition from the regimen animarum to the Reason of State.
\end{abstract}

KEYWORDS: Esotericism. Politics. Renaissance.

\footnotetext{
* Professor do Departamento e do Programa de Pós-Graduação em História da Universidade Federal de Santa Maria (UFSM), Santa Maria, RS, Brasil. Doutor em História pela Universidade Federal de Minas Gerais (UFMG).

E-mail:kirijy@gmail.com.

https://orcid.org/0000-0003-4263-8814
} 


\section{Introdução}

Em sua obra seminal, Pensando com demônios (2006, p. 688), Stuart Clark disse que só era possível se falar em uma dimensão mágica da política porque havia uma dimensão política da magia. Clark formulou isso tendo em mente principalmente a forma como a perseguição às feiticeiras podia ser usada para legitimar — ou arruinar — uma autoridade política. Contudo, pensamos que tal ideia pode ser extrapolada. Dialogando com sir James George Frazer, com as devidas ressalvas, e seu O Ramo Dourado lembramos que o cerne de sua discussão foi a forma como o monopólio de um tipo de saber de natureza mágica possibilitou a um conjunto de indivíduos a aquisição de poder político, raciocínio desenhado a partir da sucessão do sacerdote-rei do sagrado Vale Nemi, território da deusa Diana. Ao avançarmos no tempo, contudo, percebemos que tal fenômeno não é apanágio da Antiguidade ou dos primeiros ares da chamada Europa moderna. O Czar Nicolau II tentava lidar com as intempéries políticas que assolavam o seu governo consultando necromantes, a fim de obter o auxílio de seu pai, ou contratando notórios ocultistas como o francês Philippe Encausse, o Papus, e o "demônio sagrado”, Grigori Rasputin ${ }^{1}$. A cúpula nazista viu em Adolf Hitler, entre outras coisas, o avatar do Vrill, a força energética que moldaria o mundo em uma forma superior ${ }^{2}$. O chefe do MI5 deu alta patente - e soldo condizente - a um notório charlatão que o convenceu de que somente seus dons sobrenaturais poderiam dar aos Aliados meios de contrabalançar as forças místicas que os nazistas usavam como principal arma de guerra (NORTON-TAYLOR, 2008; MILMO, 2008; LONDRES USOU..., 2008). Fernando Collor de Melo, presidente impichado do Brasil, foi acusado por sua ex-mulher de ter sido eleito graças a rituais de "magia negra" (ROSANE COLLOR CONFIRMA..., [2012?]; PF DESCOBRE..., 2015). A presidente sul-coreana Park Geun-Hye, impichada em 2017 sob a acusação de corrupção, teria, entre outras coisas, favorecido ilicitamente uma amiga, Choi Soon-il. Esta última era filha e herdeira espiritual de Choi Tae-min, líder da seita Igreja da Vida Eterna. A proximidade entre a ex-presidente e a família Choi teria como base os poderes extranaturais que eles afirmavam possuir, como a capacidade de se comunicar com a falecida mãe de Park (SOUTH KOREA'S..., 2018; JENNINGS, 2016). Com estes poucos exemplos, vê-se que as relações entre a política e as forças esotéricas ${ }^{3}$ permanecem tão sólidas quanto sempre foram.

Entretanto, apesar da amplitude da seleção dos exemplos apresentados, a presente reflexão tem bem definidos os seus recortes. Como personagens tomaremos o bispo alemão Johannes Trithemius (1462-1512), o poeta e dramaturgo italiano Giambattista della Porta (c. 1540-1615) e o jurista e médico alemão Heinrich Cornelius Agrippa von Nettesheim (1486-1535). Quanto à delimitação espacial, trataremos da Europa ocidental, principalmente da Itália e da Alemanha, entre os séculos XV e XVII. Dois espaços cujas dinâmicas políticas no momento histórico delimitado se mostram distintas daquilo que apresentam em nossos dias. As terras germânicas eram um conjunto articulado de, aproximadamente, 300 "estados" semiautônomos, como cidades-livres, bispados principescos, condados e um crescente número de principados poderosos, sob o comando de indivíduos como o Eleitor de Brandenburgo, o duque da Baviera, o Eleitor da Saxônia e o Eleitor Palatino, tudo sob a liderança do Imperador do Sacro-Império Romano (GREEN, 1984, p. 114). Logo, o poder exercido pelo imperador era de tipo senhorial e volúvel, na medida em que se dava pelo arranjo de todas essas forças complexas. Isso se comprova pela simples observação de que o acesso à coroação imperial não se dava por simples hereditariedade, mas através da votação dos Príncipes Eleitores. É significativo apontar que Maximiliano I (1459-1519), a quem o abade 
Johannes Trithemius dedicaria inúmeros trabalhos esteve, em boa parte de seu governo, às voltas com movimentos que buscavam reformar a autoridade imperial e deixá-la sob controle, como foi o caso do movimento encabeçado por Berthold de Henneberg (1442-1504), Arcebispo-Eleitor de Mogúncia desde 1484(GREEN, 1984, p. 115). Em 1519, Maximiliano I foi sucedido por seu neto, que se tornaria Carlos V (1500-1558), que teve como um de seus cronistas Cornelius Agrippa.

As terras italianas viam-se disputadas por várias frentes distintas. Ao sul, havia os Estados Marítimos, como Veneza, que tinha crescido em poder desde as Cruzadas e se consolidado ao controlar o Mediterrâneo, ao menos no tocante à ação europeia. Ao norte, as cidades-estados formadoras do Regnum Italicum lutavam para garantir o direito ao autogoverno e a consequente liberdade, contra os esforços de dominação vindos tanto do imperador quanto do papa, como apontava o historiador alemão Oto de Freising já no século XII (SKINNER, 1996, p. 25). Não fortuitamente foi nessa região que se deu toda uma renovação da linguagem e da discussão política que daria origem a boa parte do debate sobre a Razão de Estado ${ }^{4}$ da qual nos falou Francesco Guicciardini (1483-1540), entre outros. No centro das terras itálicas, havia ainda o antagonista clássico do Sacro Império: o papado. Ao contrário do concorrente, o papado configurou-se como uma instituição de matiz espiritual, mas com atuação secular, cuja continuidade no tempo e no espaço foi quase ininterrupta na experiência da Europa Ocidental e cujo alcance ultrapassava e muito ao do Império, dado que o papa era, ao menos em teoria, a cabeça que guiava o corpo da cristandade. Os Estados Papais, fincados no centro da Península Itálica, colocavam-se em disputa com o Sacro Império pelo controle do Regnum Italicum (SKINNER, 1996, p. 34-44). Notemos que durante essa disputa entre vários agentes políticos pela supremacia sobre o território italiano, o papa Alexandre VI, também conhecido como Rodrigo Bórgia (1431-1492), inocentou Pico dela Mirandola (1463-1494) de todas as acusações lançadas sobre ele em função de suas 900 Theses, que dialogavam profundamente com o hermetismo e a cabala, e que Giambattista della Porta foi convocado à Roma em função das atividades realizadas em sua Academia dei Segreti e inocentado, em troca de escrever uma peça em homenagem ao papa (DARAGON, 1913, p. IV).

Consideramos fundamental apresentar algo mais de nossas personagens, a fim de tornar a discussão de suas obras mais rica. A trajetória de vida de tais sujeitos imbricou de forma muito interessante questões de ordem política e a busca pelo conhecimento esotérico, como veremos a seguir.

\section{Johannes Trithemius: exortador monástico, abade dedicado e mestre do segredo esotérico}

No ano de 1462, nascia, em Tritenheim, Johannes Zeller de Heidenberg, que adotaria o nome Johannes Trithemius ao entrar para a vida monástica. Um dos primeiros conflitos que surgiu em sua vida adveio da morte de seu pai e da chegada de seu padrasto, de nome Zell ou Cell (COULIANO, 1987, p. 164). Esta tensão vinha do desejo do jovem Johannes em adquirir luzes e do fato de seu padrasto considerar isso um desperdício de tempo e de recursos financeiros. Entre surras e sonhos miraculosos onde um anjo lhe trazia tábuas com acesso ao conhecimento, Johannes pode empreender sua peregrinação acadêmica por vários territórios alemães e pelos Países Baixos, graças ao patrocínio de Peter Heildenberg, seu tio paterno. Nessa época da juventude, Johannes tomou contato com o studium generale (MCLEAN, 1982, p. 1-5) e criou laços com grandes nomes do humanismo alemão que se tornariam seus parceiros intelectuais para a vida, como Johann Von 
Dalberg (1455-1503), Conrad Celtis (1459-1508), que foi bibliotecário de Maximiliano I e a ponte de comunicação entre o futuro abade e o imperador, Jacob Wimpfeling (1450-1528) e Johannes Reuchlin (1455-1522) (BRANN, 1999, p. 5), esse último possivelmente quem lhe apresentou a cabala.

Em janeiro de 1482, ocorreu um evento fundamental para a trajetória de Trithemius e da "lenda" que os seus biógrafos propagaram pela História. Ele e um amigo retornavam à Tritenheim, quando Johannes decidiu visitar o monastério beneditino de St. Martin, em Sponheim. Feita a visita e de volta à estrada, nossos viajantes são surpreendidos por uma nevasca, que os obriga a retornar a St. Martin. Johannes tomou o evento como um sinal divino que deveria abraçar a vida que o havia fascinado profundamente. Um ano passado, o agora Johannes Trithemius havia sido eleito abade e iniciado sua trajetória como reformador monástico.

Conforme aponta Noel Brann (1999, p. 6), o abade Trithemius tomou como norte de suas ações a regra de São Bento, principalmente no tocante ao cultivo da alma como trabalho monástico. A fim de recuperar seu monastério e, principalmente, seus monges, iniciou uma fervorosa campanha de cópia de obras variadas, fazendo com que, em 1505, os inventários da biblioteca apontassem a impressionante quantia de dois mil volumes, o que fez dessa biblioteca centro de peregrinação dos humanistas alemães (BRANN, 1999, p. 6). É relevante apontar que boa parte desses volumes tratavam de temas esotéricos, como era o caso do Picatrix, Liber Raziel, Quatro Anéis de Salomão e o Espelho de Alexandre o Grande (ZAMBELLI, 2007, p. 101-112), este último uma provável versão do famoso Secretum Secretorum do Pseudo-Aristóteles.

Esse mesmo fervor pelos livros e o conhecimento advindo dos mesmos foram as razóes pelas quais o abade seria obrigado a se afastar de sua adorada biblioteca. Revoltados pela árdua rotina no scriptorium, os monges subordinados a Trithemius insurgiram-se, tornando sua permanência como abade insustentável. A convite de Joaquim de Brandenburgo (1484-1535), Trithemius ficou em sua corte, na cidade de Colônia, até 1506, quando obteve nova posição de abade, agora no monastério de St. Jacob, em Würzburg, onde permaneceria até a sua morte (BRANN, 1999, p. 8).

\section{Giambattista della Porta: dramaturgo, poeta e magus naturalis}

Giambattista della Porta nasceu e permaneceu a maior parte de sua vida em Nápoles, um dos centros mais importantes para os humanistas italianos e, nesse momento, vértice da disputa entre Habsburgos e Valois, dada como herança de Carlos V a seu filho, Filipe II, como parte do Império (GREEN, 1984, p. 77, 165, 229).

Giambattista e seu irmão, Giau Vicenzo della Porta, foram criados por um tio, abastado e erudito o bastante para perceber o potencial de seus sobrinhos e investir em sua formação. Assim, os irmãos della Porta puderam empreender sua peregrinação acadêmica por várias bibliotecas e universidades, em terras francesas, espanholas, italianas, inglesas, germânicas e mesmo lusitanas. Ao retornar à Nápoles, Giambattista dedicou-se a todas as formas pelas quais poderia não apenas compreender o mundo natural, mas nele intervir, recorrendo sem pruridos aos saberes esotéricos. Partícipe da fundação da Academia dei Oziozi, anos depois ele mesmo fundaria um espaço semelhante, a Accademia dei Segreti. Nesse ambiente, só seriam aceitos indivíduos que teriam produzido algum avanço no tocante à doma dos mistérios do mundo natural, não importando os meios escolhidos para tal feito. Não tardou para que as atividades de Giambattista e sua Accademia fossem 
conhecidas em Roma, recaindo-lhe várias acusações, entre elas a de realizar a herética proeza de perscrutação do futuro. Convocado à Roma, della Porta afirmou tratar-se as acusações de calúnias de invejosos ignorantes e de que suas açóes não teriam nada de interdito. À troca de um juramento de encerrar as atividades de sua Accademia dei Segreti, bem como de produzir uma comédia em ode ao papa, dada a fama do napolitano como dramaturgo, o Sumo Pontífice invalidou todas as acusações contra o della Porta (DARAGON, 1913, p. II-IV).

De volta à Nápoles, della Porta dedicou-se aos estudos esotéricos, a variadas experimentaçóes para compreender as engrenagens que moviam o mundo natural - sendo inclusive tido como inventor do microscópio - e a composição de um afamado gabinete de curiosidades, atividades às quais se dedicou até a sua morte.

\section{Cornelius Agrippa von Nettesheim: o mais famoso mago de sua época ou um charlatão arrependido?}

Nascido no seio de uma família da aristocracia média de Nettesheim, cidade próxima a Colônia, no ano de 1486, Cornelius Agrippa Von Nettesheim viveria os seguintes cinquenta anos de forma muito atribulada. Obteve sua primeira formação em Colônia entre 1499 e 1502. Depois disso obteve em Paris o título de master artium, mesma época onde integrou uma sociedade de ajuda-mútua cujos membros estavam envolvidos com o aprendizado de assuntos esotéricos. Obteve um doutorado em teologia enquanto lecionava em Dôle, na Burgundia. O objeto de seu curso foi a obra cabalística do alemão Johannes Reuchlin, De Verbo Mirifico (VALENTE, 2006, p. 4).

Agrippa atuou em ocupações distintas ao longo da vida. Oriundo de uma família com longas ligações imperiais, foi capitão no exército de Maximiliano I, conquistando o título de ritter (cavaleiro). Também atuou militarmente nas disputas entre franceses e tropas imperiais no Regnum Italicum, entre 1511 e 1518, alternando os lados em suas empreitadas. Foi professor nas universidades de Dôle e de Pavia, envolvendo-se em querelas acerca de suas opinióes catedráticas em Londres e Colônia. Após uma curta estadia na corte de Carlos III, duque de Sabóia, conseguiu um posto de advogado público e de defesa na cidade imperial livre de Metz, no ano de 1518. Num ambiente onde as tensões religiosas efervesciam, demonstrou simpatia moderada a Lutero e demais reformadores. Isso, associado à sua atuação na defesa de uma mulher acusada de bruxaria - onde o principal argumento de defesa era a supremacia do sacramento do batismo sobre o pacto demoníaco, fazendo com que a acusação do inquisidor dominicano incorresse na heresia de afirmar o contrário -, foi o suficiente para jogá-lo em desgraça com os dominicanos, fazendo-o abandonar a cidade e seu trabalho.

Entre 1523 e 1524, atuou como médico em Genebra e Friburgo, respectivamente. Após esse período, Agrippa finalmente cairia nas graças de uma figura importante, Louise de Savóia, após a tentativa frustrada de ganhar as graças de Margaret da Áustria ao escrever De nobilitate et praecellentia foeminae sexus (1509), onde defendeu a supremacia da mulher sobre o homem. O cargo de médico na corte da Rainha Mãe Francesa logo se mostraria uma decepção: ela queria o Agrippa astrólogo e não o médico. Contrariado, logo caiu em desgraça com a rainha, tendo mesmo seus pagamentos suspensos, fazendo-o abandonar a corte francesa sendo alvo de chacota e endividado.

A sorte sorriria para Agrippa somente em 1528, quando obteve uma posição como conselheiro e historiador da governante dos Países Baixos, Margaret da Áustria. Em Antuérpia, Agrippa 
teria vivido uma das melhores épocas de sua vida. Finalmente sob as graças de Margaret, Agrippa se dedicava a escrever discursos, trabalhos historiográficos e mesmo participou de uma expedição contra os turcos. Nesse meio tempo, pode dedicar-se profundamente aos estudos de ordem esotérica. Em 1529, Antuérpia foi varrida por um surto de peste e, com ele, veio mais um período de atribulações para Agrippa. Único médico a permanecer na cidade durante a crise, seria posteriormente acusado e condenado pelos demais médicos por charlatanismo. Por meio de privilégio imperial, publicou em 1530 a obra De incertitudine et vanitate scientiarum declamatio invectiva, na qual se defendia de equívocos de fé e de envolvimento em artes ilícitas. O mea culpa textual não teve o efeito esperado: passou a ser perseguido sob a acusação de envolvimento com heresias. Ainda que não tenha sido efetivamente julgado por isso, sua obra foi banida de centros importantes como a Sorbonne. Somado a isso, Agrippa caiu mais uma vez em desgraça na corte e teve seus pagamentos suspensos, chegando a ser preso por dívidas em Bruxelas, no ano de 1531. Foi em Antuérpia que conheceu Johann Wier (1515-1588), seu discípulo, defensor póstumo e única fonte sobre os últimos anos do mestre. A derradeira batalha de Agrippa foi à defesa de sua obra mais conhecida, De Occulta Philosophia libri tres, pela qual foi acusado de heresia e associação demoníaca. Curiosamente foi sepultado em uma igreja dominicana, cuja ordem teve uma disputa constante com Agrippa, em Grenoble. Esse era o último ato de uma vida cheia de tragédias. Casado três vezes, enviuvou por duas vezes. Na primeira vez, sua esposa foi morta por uma doença para a qual o médico Agrippa desconhecia cura, na segunda vez, o surto de peste em Antuérpia não lhe poupou a companheira. $\mathrm{Na}$ terceira vez, traído, repudiou a esposa. O cosmos não foi piedoso com um homem que alegava conhecer seus mistérios.

\section{Esoterismo e política: relação possível ou provável?}

A partir dessas considerações sintéticas sobre nossas personagens, discutiremos como o esoterismo se relacionou com a política europeia no espaço de tempo entre os séculos XV e XVII. Pudemos perceber que todas as personagens - Trithemius, della Porta e Agrippa - estiveram envolvidas com atores centrais do teatro político daquele momento. Observando algumas de suas obras principais, entraremos na discussão das formas pelas quais o esoterismo e a política se relacionaram nesse período.

Por volta de 1500, acredita-se que a obra mais emblemática de Trithemius tenha sido terminada. A Steganographie: Ars per occultam scripturam animi sui voluntatem absentibus aperiendi certu - leitura de cabeceira do célebre mago da corte elisabetana John Dee (1527-c. 1608) - é o conjunto de

todos os métodos, maneiras, diferenças, qualidades e métodos desta nossa arte, à qual chamamos steganographia, (contendo segredos, enigmas mistérios completamente claros para nenhum homem mortal, por mais erudito ou sábio) que nunca pode ser completamente descoberta (TRITHEMIUS, 1621, p. 6, tradução nossa) 5 .

Tal método se propunha um conjunto de artifícios que misturavam magia angélico-planetária com técnicas criptográficas para transmitir mensagens sigilosas à longa distância por meio de entidades primeiramente identificadas como spiritus aerius e depois como anjos planetários 
(TRITHEMIUS, 1621, p. 6). Tal obra é composta por três livros, sendo o último incompleto. No primeiro livro, os espíritos aéreos foram alocados em conformidade com elementos do mundo natural, como os ventos, as direçôes geográficas, rios, bosques e assim por diante. No segundo livro, os doravante nomeados anjos planetários foram distribuídos em função das horas do dia e da noite e no terceiro livro, os anjos planetários foram associados de forma imediata com os planetas. Em todos os casos se repete uma estrutura ritual: o invocador deveria ter uma carta em mãos, cujo conteúdo teria a função de desviar as atenções do segredo verdadeiro, se voltar para a direção ou elemento apontado no conjuro, repetir a invocação adequada e transmitir o segredo ao espírito planetário que invocou. Para receber a mensagem secreta, o receptor deveria realizar a contra invocação correta, a fim de obter a informação desejada e não uma retaliação da entidade transmissora do segredo. O que se percebe é que o ritual se complexifica em tom crescente do primeiro para o último livro. Como exemplo de tais espíritos, trazemos alguns anjos planetários exclusivamente dedicados à política:

- Barmiel: anuncia as rendições secretas de acampamentos e cidades, principalmente nas horas de escuridão;

- Gediel: especialmente devotado aos príncipes, deve anunciar qualquer coisa que seja em benefício para os amigos e aqueles a quem apoiamos;

- Asyriel: anuncia os planos secretos dos príncipes aos seus amigos e seus súditos;

- Armadiel: anuncia aos príncipes e a todos os grandes homens as mais secretas mensagens com confiabilidade e furtividade;

- Baruchas: porta as mais ocultas e secretas comissões dos príncipes, nobres e mestres para seus servos; e

- Menadiel: é confiável em comissões e é o melhor mensageiro dos assuntos importantes de reis e príncipes (MENDONÇA JÚNIOR, 2009, p. 115-117).

Trithemius também compôs a Polygraphiae libri sex, Ioannis Trithemii Abbatis Peapolitani, quondam Spanbeimensis, ad Maximilianum Caesarem, em 1508, onde retomou o tema da comunicação secreta. Ainda que tenha afirmado que esta obra estaria "livre dos erros da fé", a mesma possui profunda inspiração não apenas na cabala, como também no hermetismo e reportou diretamente a magos notórios, como Honório Tebano e seu Liber Iuratus. Ainda, em 1508, também escreveu o De septem secundeis id est intelligentiis sive spiritibus orbes post Deum moventibus, obra na qual apresentou uma história do mundo em função da influência dos anjos planetários sobre o mesmo. Em tal obra, Trithemius (1568, p. 3-4), possivelmente influenciado pelo Heptameron de Pietro d'Abano (c. 1257-1316), defendia que o universo era governado por anjos planetários que se revezariam no comando das relaçóes supra e sublunares por períodos sucessivos de exatos trezentos e cinquenta e quatro anos e quatro meses, repetindo-se ciclicamente desde a aurora dos tempos. Logo, o abade apresentou um recenseamento de como cada anjo planetário, através de seu influxo específico, influenciou a história humana. A ousada proposta de Trithemius permitiria não apenas compreender o passado, mas se preparar para o presente e antever o futuro, dado que as influências angélico-planetárias seriam sempre as mesmas em cada governo específico. Lembremos que os esforços de predição do futuro implicavam em heresia, tanto que o historiador romeno Ioan Couliano (1987, p. 174) acreditava que fosse esse o motivo do terceiro livro da Steganographia ter sido mantido incompleto. 
Já Giambattista della Porta possui duas obras relativas aos temas esotéricos: Magiae naturalis, sive de miraculis rerum naturalium libri IIII, originalmente publicada em 1558, e De Furtivis Literarum Notis vulgo De Ziferis: libri III, cuja primeira edição conhecida data de 1563. A primeira obra ocupa-se em explicar o que é a magia natural, por quais meios opera e, ao longo principalmente do segundo e do terceiro livros, discorrer sobre as aplicaçóes possíveis para a mesma, indo da metalurgia à botânica, passando pela cosmética. Ressaltamos que se reservam capítulos para a discussão da composição de amuletos e, o que nos importa mais detidamente agora, para a comunicação secreta. A segunda obra, por sua vez, dedica-se exclusivamente a discutir as diversas aplicações para as zipherae, que della Porta (1563, p. 51) afirmou ser "uma regra dupla para marcar as letras clandestinas e secretas, que o vulgo chama Zipherae, a saber uma visível e uma outra oculta" " cuja base de atuação é essencialmente uma enorme variação de técnicas substitutivas, como na Polygraphia de Trithemius. As técnicas criptográficas de della Porta beberam muito de conhecimentos esotéricos, principalmente da cabala e da ideia de que o mundo seria movido pelas relações de simpatia e antipatia entre as virtudes ocultas que todo elemento do universo possuiria. É interessante que no De Zipheris della Porta tenha admitido diálogo direto com as técnicas de criptografia esotérica do abade Trithemius (DELLA PORTA, 1563, p. 110-111) e de seu discípulo, Cornelius Agrippa (DELLA PORTA, 1563, p. 92-93).

Por volta de 1510, um jovem Cornelius Agrippa trocou correspondências com um Trithemius já idoso e no crepúsculo da vida. Na carta enviada por Agrippa, este relatava uma visita feita a Trithemius na qual discutiram temas variados, como magia e cabala. $\mathrm{O}$ tópico central teria sido as razões por que a Igreja teria tão maus olhos para a magia "considerada por todos os filósofos como a principal ciência, venerada por sábios antigos e sacerdotes” (AGRIPPA, 2016, p. 59). A resposta construída nesse diálogo é que o mesmo teria acontecido porque muitos falsos sábios a teriam denegrido, pois apresentaram vários equívocos e imposturas sob o nome de magia. Assim, Agrippa buscava consertar tal situação através de sua obra De Occulta Philosophia libri tres, onde seria apresentada a verdadeira magia. Relata-se ainda que a obra foi enviada para que Trithemius pudesse avaliá-la, reconhecendo nele uma autoridade, e identificar se ali havia algum equívoco e elemento ofensivos a Deus e à Igreja.

Trithemius respondeu com prontidão, elogiando que Agrippa tenha composto uma obra de tamanha erudição e acerto sendo ele ainda jovem. Entre os elogios ao autor e a sua obra, o abade se preocupou em alertar o jovem discípulo de que tal conhecimento poderia representar um perigo, principalmente para ele. Assemelhando os possíveis adversários a bois, recomendou a Agrippa que apenas comunicasse seu saber esotérico aos pássaros, pois, assim, seria possível continuar sua empreitada de conhecimento, cujos limites repousariam nos céus. Trithemius foi muito eloquente em sua advertência:

Entretanto, esta regra eu o aconselho a observar: comunique segredos vulgares a amigos vulgares, mas os segredos superiores só aos amigos superiores e também secretos. Dê feno a um boi, açúcar ao papagaio; compreenda o que quero dizer, para não ser pisoteado pelas patas do boi, como acontece com frequência (AGRIPPA, 2016, p. 64).

O De Occulta Philosophia somente seria publicado em 1533, sendo que o De vanitate... foi publicado em 1530 (WALKER, 2000, p. 90). No De Vanitate... Agrippa apresentou uma série de retratações acerca de erros de fé pregressos, incluindo seu envolvimento com variados tipos de 
magia. A mesma obra seria reimpressa ao final do De Occulta Philosophia. Essa obra, por sua vez, dividia-se em três livros, nos quais se realizou uma verdadeira enciclopédia de todo saber esotérico que circulava pela Europa de então. Agrippa tratou de magia natural, encantamentos, necromancia, goetia e teurgia, cabala, sephirots cabalísticos, humores, sufumigações, anéis mágicos, ilusionismo, das virtudes ocultas das coisas e de comunicação secreta, entre outras matérias, como discutimos anteriormente.

Entendendo a magia como a dimensão prática da filosofia natural, ou seja, da compreensão dos mecanismos que colocam o mundo em movimento, Agrippa (2016, p. 80), apresentou a seguinte definição acerca da magia:

A Magia é uma faculdade de maravilhosa virtude, cheia dos mais nobres mistérios, contendo a mais profunda contemplação das coisas mais secretas junto à natureza, ao poder, à qualidade, à substância e às virtudes delas, bem como o conhecimento de toda a natureza, e elas nos instrui acerca da diferença e da concordância das coisas entre si, produzindo assim maravilhosos efeitos, unindo as virtudes das coisas pela da aplicação delas em uma em relação a outra, unindo-as e tecendo-as bem próximas por meio dos poderes e da virtudes dos corpos superiores. [...] Essa é a mais perfeita e principal ciência, a mais sagrada e sublime espécie de filosofia e, por fim, a mais absoluta perfeição de toda a excelentíssima Filosofia.

Parece confuso como o mesmo Agrippa, em um intervalo tão curto de tempo, apenas três anos, assumiu posturas tão distintas acerca de um mesmo objeto: a magia. Se ele estava tão profundamente arrependido dos seus "equívocos anteriores", por que publicar o De Occulta Philosophia, após uma espera de aproximadamente vinte anos? Concordando com Daniel P. Walker (2000, p. 90-91), entendemos que as desculpas de Agrippa devem ser olhadas com muita atenção. Em seu De Vanitate..., ele se desculpa unicamente pelo seu envolvimento com as práticas mágicas envolvendo demônios e maus espíritos, havendo mesmo uma tímida defesa da teurgia e demais conhecimentos mágicos que possibilitassem o contato com anjos, incluindo os planetários. Acreditamos que foi um estratagema de Agrippa para evitar mais problemas com a Igreja, já que vinha de uma longa história de disputas com vários membros da mesma. Uma vez mais aquiescendo com Walker, defendemos que Agrippa permaneceu acreditando na validade e potência da magia até o fim da vida.

Os trabalhos aqui apresentados têm vários elementos em diálogo, como apontaremos de agora em diante. Para começar, podemos listar a presença de diversas correntes esotéricas em comum, como o hermetismo - reavivado na Europa pela obra de Marsilio Ficino -, a cabala e seus sephirots, releituras da teurgia e da goetia gregas, a amálgama entre o anjo cristão e o daimon grego que formou a concepção de anjo planetário ${ }^{7}$ e, principalmente, a ideia de que o universo seria uma grande rede de relações simpáticas entre as virtudes ocultas emanadas da esfera supralunar de forma específica em cada indivíduo. Portanto, quem desvendasse tal intrincado mecanismo faria do universo uma lira da braccio e executaria a música que desejasse, para usar a analogia de Ficino. Essa última concepção foi ainda extrapolada, principalmente em Trithemius e della Porta - mas também em Agrippa - , na ideia de que, tal qual o Pentagramaton e Tetragramaton cabalísticos (os nomes secretos de Deus), as palavras tem uma dimensão oculta no bojo da qual podem carregar mensagens secretas, alicerce das técnicas de comunicação secretas anteriormente discutidas ${ }^{8}$. Portanto, assim como o cabalista efetuaria a ação de poder ao proferir os nomes ocultos de Deus, a linguagem secreta repousaria sua efetividade na sua capacidade de realizar dois níveis de comunicação em um único signo. 
A capacidade da comunicação secreta de atuar a qualidade oculta da palavra possibilitava que se criasse um espaço de atuação por meio da proteção do Segredo através das estratégias de Sigilo. Conforme reflete Michael Jucker (2006, p. 275-276), segredo e política têm uma relação muito importante para as mecânicas do que entendemos por "Estados Modernos", tanto no que toca a sua fundação quanto em respeito à sua manutenção. Dessa forma, produziu-se todo um esforço para construir - ou destruir — os véus de Sigilo lançados para proteger aquilo que se desejava secreto. Podemos elencar os mais diversos estratagemas, como subornos, tortura, espionagem, “órgãos de inteligência” e as técnicas de comunicação secreta às quais já mencionamos. Dessa forma, por meio de técnicas de Sigilo, como a linguagem cifrada, que buscavam dar acesso seletivo a algum tipo de informação, o Segredo, construía-se uma rede de poder baseada no acesso - ou não - daquilo que se intentava secreto. Ainda concordando com Jucker (2006, p. 75), as relaçóes de Sigilo e Segredo tornavam-se um elemento capaz de desestabilizar sociedades e comunidades, em maior ou menor escala. Portanto, essa história das relações entre Segredo e Sigilo mostra-se uma rica fonte de informações acerca de relações e práticas políticas de um dado período.

Dito isso, é interessante construir uma definição mais precisa acerca do que entendemos como Segredo e Sigilo. Douglas Biow (2002, p. 155) aponta que a função social do Sigilo não é, de fato, ocultar o conhecimento, mas que se detêm tais informaçóes. Lembrando que nisso Biow e Jucker convergem, só é possível uma reflexão acerca das relações entre Segredo e Sigilo, pois elas fracassaram em seu intento original. Portanto, o Segredo - quase sempre - não constitui um conjunto de informações realmente desconhecidas de todos. Os segredos de ordem esotérica, na verdade, quase sempre eram conhecidos, sendo o Secretum Secretorum (MENDONÇA JÚNIOR, 2014, p. 310) um bom exemplo dessa situação. Assim, o Segredo trata muito mais de acesso do que de conteúdo, ou seja, de criar relações hierárquicas de poder pautadas pela possibilidade de romper - ou não - os véus do Sigilo.

Se assim podemos pensar o Segredo, imediatamente somos compelidos a refletir sobre o Sigilo. Este pode ser definido como todo e qualquer conjunto de esforços direcionados a ocultar algo. Assim, podemos elencar espionagem, determinados tipos de correspondências e as supracitadas formas de linguagem cifrada, entre outras possibilidades. Tal jogo entre Segredo e Sigilo tem como objetivo último criar relações de poder hierarquizadas, em outros termos, separar os indivíduos em dois grupos: "aqueles que sabem e podem saber" e "aqueles que não sabem e não podem saber". Exatamente na tensão entre a ignorância e o conhecimento, no desejo de tornar-se "aquele que sabe” é que reside a potencialidade das relaçôes de poder acima discutidas. Uma vez desvelado o Segredo, este se torna inerte, esvaziado de possibilidades de ação. Só existe um espaço de atuação política enquanto os véus do Sigilo permanecem intactos ao redor do Segredo, enquanto "aquele que sabe e pode saber" ainda tem algo a oferecer "aquele que não sabe e não pode saber" esforços de Trithemius, della Porta e Agrippa inserem-se justamente nessa dinâmica, pois buscam meios de ofertar as técnicas de Sigilo adequadas para proteger o Segredo do Princeps.

Um elemento importante a se notar é que tais obras são fruto, aproximadamente, da primeira metade do século XVI. Como apontamos anteriormente, nesse espaço de tempo temos os conturbados governos de Maximiliano I e de seu neto, Carlos V. A Steganographia foi dedicada ao Lorde Felipe, Conde Palatino do Reno e Príncipe Eleitor do Sagrado Império Romano, sendo a Polygraphia e o De Septem Secundeis... dedicadas diretamente a Maximiliano I, com quem o abade esteve pessoalmente em 1508. Trithemius encontrou-se envolvido diversas vezes com o imperador. 
Em uma oportunidade, escreveu-lhe um texto exortando-o ao combate à praga da feitiçaria que assolava as terras germânicas, em outra oportunidade dedicou a responder dúvidas teológicas do imperador (COULIANO, 1987, p. 162). No De Septem Secundeis..., o abade não titubeou a reconhecer no imperador a única força capaz de colocar o mundo nos seus devidos eixos:

Donde seja necessário teu governo ó gloriosíssimo César Maximiliano, assim como vestir a pele hercúlea, e vibres a clava nas mãos, e foi dado a ti por Deus o empreendimento de purgar o mundo destes monstros [que o] assolam. Nunca existirá paz no reino [a menos que] sejam suprimidos os bacuceus do meio. Que perturbam a paz do reino, se esse reino demonstra [ter] inimigo. Estes são ladróes que assediam os caminhos itinerantes, pilham outros, dos quais hoje a terra está cheia, e jamais é segura a caminhada na estrada (TRITHEMIUS, 1518, p. 522) ${ }^{10}$.

Preocupação semelhante vemos na argumentação de Giambattista della Porta (1563, p. 2), que afirma viver "em tempos quando a mais completa licença prevalece, e quando ninguém ousa proibir crimes”11. Trithemius (1518, p. 521-522) também afirmou viver

em um tempo em que prevalece a liberdade para pecar, não se pode encontrar nenhum lugar seguro no mundo. Tomem e firam daqui e dali os mensageiros dos príncipes [que] se enfurecem [devido às] crueldades dos ladróes, [e] quase todos poupam os ladróes ímpios ${ }^{12}$.

Lembremos que Agrippa lutou no exército de Maximiliano I, tornando-se inclusive seu cavaleiro, e passou boa parte da vida em peregrinação por diversas cortes europeias, como as que circundavam Carlos III, duque de Savóia, Louise de Savóia e Margaret da Áustria. Além de Trithemius, outro agraciado com uma cópia dos três livros do De Occulta Pilosophia foi Hermano de Wied (1477-1552), conde de Wyda, arcebispo de Colônia, duque da Westfália, chanceler-chefe pela Itália e príncipe eleitor do sacro Império Romano. Na correspondência trocada com Hermano, Agrippa justificou o presente, pois o considerava o grande feito de sua vida e esperava que, por meio do leitor ilustre, a sua obra ganhasse projeção. Vemos que os vários infortúnios que acompanharam a trajetória de Agrippa se refletiram igualmente nessa correspondência. Já na segunda carta, ele se justificava ante o duque da Westfália, ao afirmar ser vítima de calúnias, vindas de homens ignorantes que tomavam por erros e agressóes à fé a sua tão importante contribuição. Como cada livro do $D e$ Occulta Philosophia foi acompanhado de uma carta, na terceira delas, Agrippa apelou para a "bondade" e a "agudeza de sentidos" de Hermano, para que esse reconhecesse que ali estava ofertada a sabedoria dos antigos, que recebera ao longo da História o nome de magia. Enfim, Agrippa tentava convencer Hermano de que, por meio de seu presente, abria para o ilustre patrono o caminho para a realização de prodígios maravilhosos (AGRIPPA, 2016, p. 65-66, 341-342, 580-582).

\section{Considerações finais}

A preocupação central da presente reflexão é entender os meios pelos quais política e esoterismo se relacionaram na Europa dos Séculos XV e XVI. Para isso, ocupamo-nos da trajetória de vida de Trithemius, della Porta e Agrippa, bem como de suas principais obras. Buscamos demonstrar que estes indivíduos estiveram envolvidos, simultaneamente, com as grandes questóes políticas de sua época, bem como com a efervescente busca humanista pelo saber esotérico. 
Tanto Trithemius quanto della Porta se percebiam como parte de um mundo conflituoso, caótico, onde o crime e o perigo campeavam. Della Porta via como causa dessa situação a desobediência pelas leis, enquanto o abade considerava que a raiz do problema era o desrespeito à figura principesca. Contudo, ambos concluíram que a solução do imbróglio residia no fortalecimento do governante. Para della Porta, apenas o governante poderia garantir o adequado e correto cumprimento das leis, enquanto Trithemius entendia a figura imperial como a garantia do bem comum. O napolitano viveu em uma Nápoles disputada pelo Papado e pelo Império, ao mesmo tempo em que lutava pelo direito de autogoverno e de liberdade; Trithemius e Agrippa em um território germânico sacodido pelas tentativas de controle da autoridade imperial por meio de reformas políticas diversas. Tanto della Porta quanto Trithemius percebiam - cada qual por seu motivo - a necessidade de um governante forte, pois só assim poderia haver ordem. A crescente complexificação do mundo político de então, marcado pela transição entre o Regimen animarum e a Razão de Estado, tornava central os cuidados de Sigilo acerca dos Segredos do príncipe. Empregavam-se para tal propósito secretários, chancelarias e criptografia a fim de manter tais segredos ao alcance "daqueles que podem saber" e protegidos “daqueles que não podem saber". Assim, tanto o abade quanto o dramaturgo buscavam ofertar ao princeps, por meio de suas linguagens cifradas de natureza esotérica, a Virtù necessária para domar a Fortuna, em outras palavras, os meios adequados para garantir Sigilo aos seus Segredos. Jean-Pierre Cavaillé (2008) traz a oportuna definição de dis/simulação política, segundo a qual ao dissimular um conhecimento e simular outro se criaria um espaço de ação política justamente na tensão entre conhecido e desconhecido. Dessa forma, o que ambos ofertavam por meio de uma criptografia esotérica era exatamente esse espaço de atuação, no qual se seria virtuoso enquanto imperasse a dúvida entre o revelado e o secreto.

Não nos esqueçamos de nossa outra personagem. Agrippa também tratou de comunicação secreta, em verdade, comparativamente, a sua obra é muito mais abrangente e rica em termos de conhecimento esotérico do que a das outras duas personagens aqui tratadas. Assim como Giambattista della Porta, ele também veio de uma família bem posta e como Trithemius também percorreu e atuou em cortes de primeira grandeza europeia. Então, porque o abade e o dramaturgo tiveram aparente sucesso em suas relações com os poderosos, enquanto Agrippa foi diversas vezes escorraçado e humilhado, chegando a ser preso por dívidas? A nossa hipótese reside no conselho que lhe foi dado pelo próprio Trithemius: de que reservasse os segredos importantes apenas aos amigos importantes. $\mathrm{O}$ abade dedicou suas obras e relacionou-se com poderosos príncipes palatinos, como Joaquim de Brandenbrugo, bem como com o próprio Maximiliano I. Mesmo as acusaçóes feitas em 1504 por Picard Charles Bouelles ou Bovillus (c. 1470-c. 1553) (BRANN, 1999, p. 7-10), de que Trithemius tratava de demonomagia em sua Steganographia, foram insuficientes para fazê-lo cair em desgraça, lembrando que sua mudança de Sponheim a Würzurg nada teve a ver com isso, inclusive não foi impeditivo para que ele permanecesse em alta posição eclesiástica. $\mathrm{O}$ mesmo temos com della Porta e suas obras dedicadas a Felipe II, conhecido patrono de alquimistas, haja visto todo o investimento feito por ele para criar um centro alquímico em El Escorial (BUBELLO, 2010; EAMON, 2010). Enquanto isso, Agrippa escolheu como patrono Hermano de Wied, príncipe -eleitor e arcebispo de Colônia desde 1515. Contudo, o eclesiástico mostrou-se ao longo do tempo muito favorável à Reforma, inclusive convidando Martin Bucer, amigo de Martinho Lutero, para ajuda-lo em seus esforços reformadores a partir de 1536. Em consequência disso, Hermano seria convocado pelo papa Paulo III em 1546, deposto e excomungado (AGRIPPA, 2016, p. 1017). 
Afora a infeliz escolha de patrono, Agrippa não se privou de polemizar com autoridades eclesiásticas, além de construir animosidades pelas cortes pelas quais passou, a ponto de escrever para um amigo que vivia na corte e chama-la de Inferno e escola de vilezas (AGRIPPA, 2016, p. 870).

Indicadas algumas dimensões das relações entre política e esoterismo que permearam o palco europeu entre os séculos XV e XVI, resta-nos apontar que essas são reflexões que ainda exigem maior fôlego e aprofundamento. Contudo, não nos parece arriscado afirmar que nesse mundo onde o poder deixava de ser uma concessão divina para a garantia da salvação das almas cristãs para se tornar um bem pessoal do princeps - algo a se conquistar, manter e expandir como diria Maquiavel -, mais do que nunca se mostrava fundamental investir seus segredos apenas em empreitadas cujo retorno fosse garantido, como aliar-se a um imperador. Por meio de uma maré sem fim de revezes, fracassos e perdas dolorosas, passando do jovem mago talentoso ao "charlatão" arrependido e dúbio, Agrippa entendeu do pior jeito quão prejudicial é dar açúcar ao animal errado.

\section{Referências}

AGRIPPA, Heinrich Cornelius. Três livros da filosofia oculta. São Paulo: Madras, 2016.

BIOW, Douglas. Doctors, ambassadors, secretaries: humanism and professions in Renaissance Italy. Chicago: University of Chicago Press, 2002.

BRANN, Noel. Trithemius and Magical Theology: a chapter in the controversy over Occult Studies in Early Modern Europe. State University of New York Press, 1999.

BUBELLO, Juan Pablo. Esoterismo y política de Felipe II en la España del Siglo de Oro: reinterpretando al círculo esotérico filipino en El Escorial: Juan de Herrera, Giovanni Vicenzo Forte, Diego de Santiago, Richard Stanihurst. Veredas da História, Brasil, v. 3, n. 2, 2010. Disponível em: http://www.seer.veredasdahistoria.com. br/ojs-2.4.8/index.php/veredasdahistoria/article/view/48/51. Acesso em: 12 fev. 2019.

CAVAILLÉ, Jean-Pierre. Dis/simulations: Jules-César Vanini, François La Mothe Le Vayer, Gabriel Naudé, Louis Machon et Torquatto Accetto. Religion, morale et politique au XVIle siècle. Paris: Honoré Champion Éditeur, 2008.

CHARTIER, Roger. À beira da falésia: a história entre incertezas e inquietude. Porto Alegre: Editora da UFRGS, 2002.

CLARK, Stuart. Pensando com demônios: a ideia de bruxaria no princípio da Europa Moderna. São Paulo: Edusp, 2006.

COULIANO, Ioan. Eros and magic in the renaissance. Chicago: University of Chicago Press, 1987.

DARAGON, H. Introduction. In: DELLA PORTA, Giambattista. La magie naturelle ou Les Secrets et Miracles de La Nature (1631). Paris: H. Daragon Libraire-Editeur, 1913. p. I-VI.

DELLA PORTA, Giambattista. De Furtivis Literarum Notis vulgo De Ziferis: Libri III. Neapoli: Apud loa Mariam Scotum, 1563.

EAMON, William. Masters of fire: italians alchemists in the court of Philip II. In: LÓPEZ-PÉREZ, Miguel; KAHN, Didier; REY-BUENO, Mar (ed.). Chymia: Science and Nature in Medieval and Early Modern Europe. Cambridge: Cambridge Scholars Publishing, 2010. p. 138-156.

FAIVRE, Antoine. O Esoterismo. Campinas; São Paulo: Papirus, 1994.

GREEN, Vivian. Renascimento e reforma: a Europa entre 1450 e 1660. Lisboa: Publicações Dom Quixote, 1984.

JENNINGS, Ralph. Five things to know about South Korea's presidential scandal. Forbes, Jersey City, 9 Nov. 2016. Disponível em: https://www.forbes.com/sites/ralphjennings/2016/11/09/5-sad-and-creepy-thingsyou-should-know-about-south-koreas-presidential-scandal/\#584980891556. Acesso em: 12 fev. 2019.

JUCKER, Michael. Secrets and politics: methodological and communicational aspects of late medieval diplomacy. Micrologus: Natura, Scienze e Società Medievali, Firenze, v. 14, p. 275-309, 2006. 
LONDRES USOU ‘astrólogo' como arma secreta contra Hitler. G1, São Paulo, 4 mar. 2008. Seção “Mundo”, subseção “História”. Disponível em: http://g1.globo.com/Noticias/Mundo/0,,MUL336304-5602,00LONDRES+USOU+ASTROLOGO+COMO+ARMA+SECRETA+CONTRA+HITLER.htmI. Acesso em:12 fev. 2019.

MCLEAN, Adam. Introduction. In: TRITHEMIUS, Johannes. The steganographia of Johannes Trithemius. Book one. Edinburgh: Magnum Opus Hermetic Sourcebook, 1982. p. 1-13.

MENDONÇA JÚNIOR, Francisco de Paula Souza de. A arte do segredo: esoterismo, sigilo e dissimulação política nos séculos XV e XVI. 2014. 404 f. Tese (Doutorado em História e Culturas Políticas) - Universidade Federal de Minas Gerais, Belo Horizonte, MG, 2014.

MENDONÇA JÚNIOR, Francisco de Paula Souza de. Artífice do segredo: o abade Johannes Trithemius (14621516) entre o magus e o secretarium do princeps. 2009. 197 f. Dissertação (Mestrado em História e Culturas Políticas) - Universidade Federal de Minas Gerais, Belo Horizonte, MG, 2009.

MILMO, Cahal. Revealed: How MI5 recruited an astrologer in plot to outwit Hitler. The Independent, London, 4 Mar. 2008. "Home News" section. Disponível em: https://www.independent.co.uk/news/uk/home-news/ revealed-how-mi5-recruited-an-astrologer-in-plot-to-outwit-hitler-790876.html. Acesso em: 12 fev. 2019.

NORTON-TAYLOR, Richard. Star turn: astrologer who became SOE's secret weapon against Hitler. The Guardian, London, 4 Mar. 2008. "National Archives" section. Disponível em: https://www.theguardian.com/ uk/2008/mar/04/nationalarchives.secondworldwar. Acesso em: 12 fev. 2019.

PF DESCOBRE 'despacho de macumba' na casa de Collor contra Janot, diz colunista. Congresso em Foco, Brasília, DF, 4 nov. 2015. Seção “Corrupção”. Disponível em: https://congressoemfoco.uol.com.br/especial/ noticias/pf-descobre-despacho-de-macumba-na-casa-de-collor-contra-janot-diz-colunista/. Acesso em: 12 fev. 2019.

ROSANE COLLOR CONFIRMA que ex-presidente praticava rituais de magia negra. Terra, São Paulo, [2012?]. Seção “Mundo". Disponível em: https://www.terra.com.br/noticias/mundo/rosane-collor-confirma-que-ex -presidente-praticava-rituais-de-magia-negra,f2d8b0afd40ea310VgnCLD200000bbcceb0aRCRD.html. Acesso em: 12 fev. 2019.

SENELLART, Michel. As artes de governar: do regimen medieval ao conceito de governo. São Paulo: Editora $34,2006$.

SKINNER, Quentin. As fundações do pensamento político moderno. São Paulo: Companhia das Letras, 1996.

SOUTH KOREA'S presidential scandal. BBC News, London, 6 Apr. 2018. “World” section. Disponível em: https://www.bbc.com/news/world-asia-37971085. Acesso em: 12 fev. 2019.

TRITHEMIUS, Johannes. De septem secundeis, id est, intelligetiis, sive spiritibus orbes post Deum moventibus, reconditissimae scientiae \& eruditionis Libellus, Imperatori Caesari Diuo Maximiliano I. Aug. pio, sapienti dicatus. Coloniae: Apud loannem Bisckmannum, 1568.

TRITHEMIUS, Johannes. Polygraphiae libri sex, Ioannis Trithemii Abbatis Peapolitani, quondam Spanheimensis, ad Maximilianum Caesarem. Oppenheim: Haselberg, 1518.

TRITHEMIUS, Johannes. Steganographie: Ars per occultam Scripturam animi sui voluntatem absentibus aperiendi certu. 4 ed. Darmstadt: Officina Typographica Balthasaris Aulæandri, 1621.

VALENTE, Michaela. Agrippa, Heinrich Cornelius. In: HANEGRAAFF, Wouter (ed.). Dictionary of Gnosis and Western Esotericism. Leide: Brill, 2006. p. 4-8.

VIROLI, Maurizio. From politics to reason of state: the acquisition and transformation of the language of politics (1250-1600). Cambridge: Cambridge University Press, 2005.

WALKER, Daniel. Spiritual and demonic Magic: from Ficino to Campanella. Pennsylvania: The Pennsylvania State University Press, 2000.

ZAMBELLI, Paola. White magic, black magic in the Renaissance Europe: from Ficino, Pico, Della Porta to Trithemius, Agrippa, Bruno. Leiden: Brill, 2007. 


\section{Notas}

${ }^{1}$ Ver mais em: WARTH, Robert. Before Rasputin: Piety and the Occult at the Court of Nicholas II. The Historian, United States, v. 47, n. 3, p. 323-337, May 1985. Disponível em: https://onlinelibrary.wiley.com/doi/abs/10.1111/j.1540-6563.1985. tb00665.x. Acesso em: 12 fev. 2019; RADCLIFFE, Jessie. Rasputin and the Fragmentation of Imperial Russia. In: YOUNG HISTORIANS CONFERENCE, 8., 2017, Oregon. Schedule. Oregon: Portland State University, 2017. Disponível em: http:// pdxscholar.library.pdx.edu/younghistorians/2017/oralpres/14. Acesso em: 12 fev. 2019.

2 Ver mais em: GOODRICK-CLARKE, Nicholas. Black sun: aryan cults, esoteric Nazism and politics of identity. New York: New York Press Books, 2001; GOODRICK-CLARKE, Nicholas. The occults roots of nazism: secret aryan cults and their influence on Nazi ideology. Londres: Tauris Parker Paperbacks, 2005.

${ }^{3}$ De acordo com Antoine Faivre (1994, p. 13-24), que o esoterismo, enquanto categoria conceitual, surge como campo possível no momento em que as "causas segundas" se emancipam da metafísica, ou seja, quando as ciências da natureza se separam da teologia, por volta do século XII. Esse Esoterismo teria seu corpus histórico formado por três eixos principais, sendo eles a alquimia, a magia e a astrologia, temperadas por uma aritmosofia; encorpados por afluentes, como a cabala cristã, o hermetismo neo-alexandrino e a ideia de uma filosofia perennis. Faivre avança afirmando que esse conjunto de práticas, representações e discursos, para dialogarmos com as categorias apresentadas por Chartier (2002), somente seriam identificáveis havendo a presença de quatro “características intrínsecas", que poderiam - ou não - ser acompanhadas de duas "características secundárias". As qualidades intrínsecas são: Correspondência (o universo seria completamente interligado por uma rede de correspondências formando um emaranhado de relações simpáticas), Natureza Viva (formada por uma multiplicidade de camadas, a Natureza poderia ser lida e manuseada como um livro, dando-Ihe operatividade), Imaginação e Mediações (a primeira corresponderia a um órgão da alma que criaria os segundos, instrumentos necessários para atuar nas relações simpáticas que moveriam a Natureza), Experiência de Transmutação (cooperação entre conhecimento e maginação ativa sobre as redes simpáticas constituintes da Natureza). As secundárias são a Práxis da Concordância (busca por estabelecer os pontos comuns entre as diversas tradições esotéricas) e a Transmissão (o conhecimento esotérico só poderia ser transmitido por um mestre a um discípulo, proporcionando-Ihe um segundo nascimento).

${ }^{4}$ Uma das grandes aquisições para o pensamento político europeu dos séculos XV e XVI foi a ideia de Razão de Estado. Até então a atuação do príncipe era regida por uma ética puramente cristã, pautada pelo governo das almas, o Regimen animarum. Conforme aponta Michel Senellart (2006, p. 27-32), o Regimen recebe um sentido político apenas tardiamente, sendo originalmente parte do vocabulário da direção espiritual. Assim, o governo das almas nasceu como uma forma de governo não violenta donde se usaria da persuasão para conduzir a alma - naturalmente reativa e indócil - a seguir o caminho que conduziria a perfeição cristã, logo à sua salvação. Essa pedagogia espiritual teria como principal arma a persuasão, sendo o exemplo do condutor o alicerce fundamental desse processo. Portanto, conforme o Regimen animarum, o governo se resume à sua função, logo é meio e não finalidade. A atividade real é diretiva, portanto, o rei conduz os súditos como uma grande família, cujo objetivo é a salvação espiritual de todos. Ainda que Nicolau Maquiavel seja o nome mais lembrado ao se pensar a crítica a esse modelo de governo, foi Francesco Guicciardini aquele que deu a primeira contribuição que efetivamente conduziu a outra possibilidade de atuação política. Conforme Maurizio Viroli (2005, p. 179), em obras como Del modo di ordinare il governo popolare e Dialogo del regimento di Firenze, Guicciardini apresentou outra visão acerca da relação entre o príncipe e o poder. Em tais obras o governo de um reino foi comparado ao comando de uma casa comercial, tendo, portanto, como objetivos centrais a ampliação da riqueza, no caso do comércio, ou do poder, no caso do Estado. Para tanto seria preciso possuir um refinado entendimento das paixões e humores humanos, bem como do mundo à sua volta. Pela precisa e astuta combinação de tais qualidades, seria possível realizar as escolhas mais adequadas a cada situação, habilidade fundamental em um mundo envolto em turbulentas transformações. Maquiavel também trouxe contribuições fundamentais a tal processo, ao defender que a habilidade política de seu "príncipe ideal" repousaria, entre outras coisas, na capacidade de aliar a experiência dos tempos modernos com o conhecimento dos feitos do passado, ferramental vital no embate contra a Fortuna. Dessa maneira, se o Regimen Animarum entendia o poder como um meio para atingir uma finalidade, a Razão de Estado compreendia o poder como um fim em si mesmo. Tal percepção permitia que o príncipe adotasse o comportamento mais adequado para conquistar, manter e ampliar seu poder, podendo ser raposa ou leão, como melhor lhe conviesse, como disse Maquiavel. Se o Regimen animarum se pautava por uma rígida moral de natureza cristã, até pela ausência de uma instância reguladora externa à vontade do rei, a ética da Razão de Estado era essencialmente móvel e camaleônica. Se o Regimen animarum idealizava um rei piedoso e reto nos preceitos da fé, a Razão de Estado preconizava o princeps virtuoso, capaz de aliar uma arguta leitura de mundo às qualidades necessárias para se proteger do imponderável. A transição do Regimen animarum para a Razão de Estado, significou a passagem de um modelo de governo onde o exemplo deveria ser a arma principal, para um no qual todos os recursos eram justificáveis para atingir seus objetivos. Com isso não dizemos que a Razão de Estado não possui uma ética, mas que ela era tão maleável quanto os desafios contra os quais se opunha. 
${ }^{5}$ No original, "ita nec huius artis nostrae, quam Steganographiam (secreta \& arcana \& mysteria, nulli mortalium, quantumcunque studioso vel erudito, patula continentem prefecte) appellamus, omnes modi, viae, differentiae, qualitates \& operationes in aeternum poterunt ad plenam fieri penetrabiles".

${ }^{6}$ No original: "De clandestinis literarum notis, quas vulgus zipherae vocat, duplicem statuunt normam visibilium unam."

${ }^{7}$ Ver mais em: GORDON, Bruce. The renaissance angel. In: MARSHALL, Peter; WALSHAM, Alexandra (org.). Angels in the early modern world. Cambridge: Cambridge University Press, 2006.

${ }^{9}$ Para uma reflexão mais profunda sobre essa ideia, ver: MENDONÇA JÚNIOR, 2009; 2014.

${ }^{9}$ Ver mais em: MENDONÇA JÚNIOR, 2014; MENDONÇA JÚNIOR, Francisco de Paula Souza de. Esoterismo, sigilo e segredo. In: BUBELLO, Juan Pablo; CHAVES, José Ricardo; MENDONÇA JÚNIOR, Francisco de Paula Souza de (ed.). Estudios sobre la historia del esoterismo occidental en América Latina: enfoques, aportes, problemas y debates. Buenos Aires: Editorial de la Universidad de Buenos Aires, 2017. p. 25-38.

${ }^{10}$ No original: “Unde foret necessarium reipubliçe tuae o gloriosissime Caesar Maximiliane, ut pellem indueres herculeam, clauamquae uibrares in manibus, et seuis his monstris orbem tibi a deo purgares commissum. Numquam pax erit in regno nisi bacucei tollantur e medio. Qui regni pacem turbat, se hostem esse regnis demonstrat. Hi sunt latrones qui uias itinerantium obsident, rapiunt aliena, quibus hodie plena est terra, et nunquam tuta est ambulantibus uia."

${ }^{11}$ No original, "in maxima praecipue temporis licentia, cum delicta vetare nemo audeat".

${ }^{12}$ No original, "te poribus, in quibus p ualente licentia peccãdi, nus qp tuta reperitur sides in orbe. Capiuntur passim nu cii principu a latronibus saeuis spoliãtur, uerberantur, \& pleru quae parcunt impii raptores".

Data de recebimento: $28 / 10 / 2018$

Data de aprovação: 03/03/2019 